\title{
Childhood Alveolar Rhabdomyosarcoma
}

National Cancer Institute

\section{Source}

National Cancer Institute. Childhood Alveolar Rhabdomyosarcoma. NCI Thesaurus. Code C7958.

An aggressive malignant mesenchymal neoplasm occurring in children. It is characterized by the presence of round cells with myoblastic differentiation, and a fibrovascular stroma resembling an alveolar growth pattern. 